تغيير يذيرى فرسايش سطحى و دانهبندى ذرات خاى نسبت به جهت و درجه شيب دامنه در منطقه نيمه خشك در غرب زنجان

علىرضا واعظى *، زهرا بيات و مجيد فرومدى'

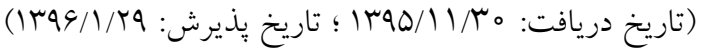

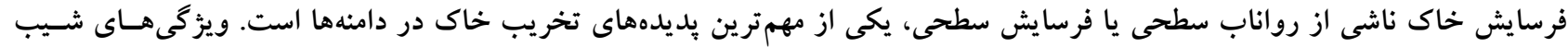

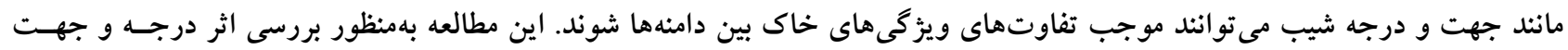

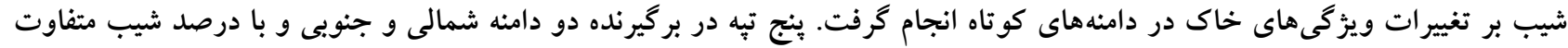

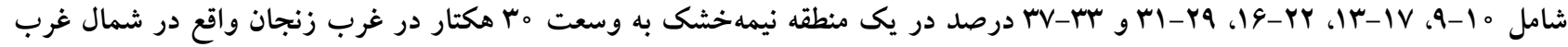

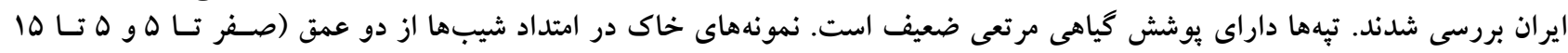

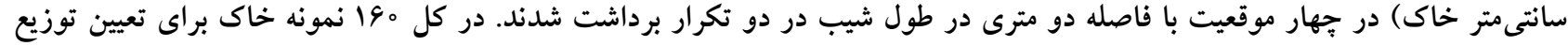

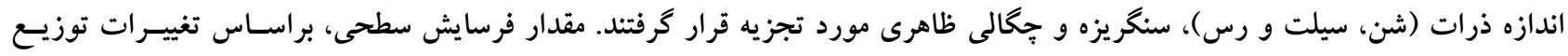

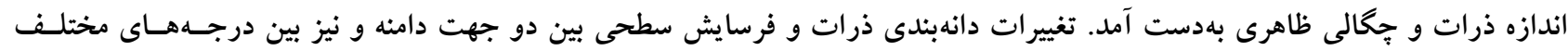

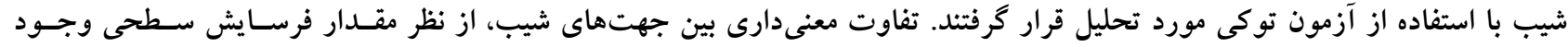

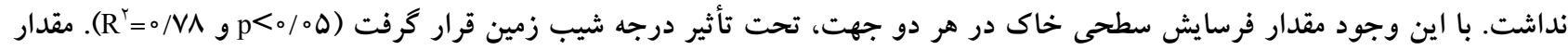

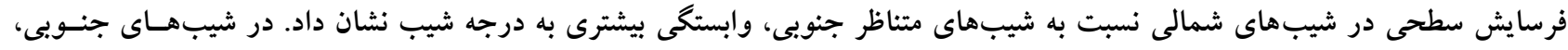

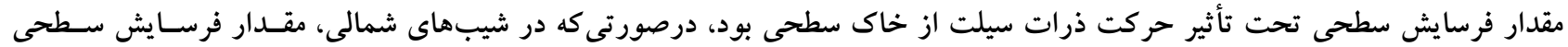

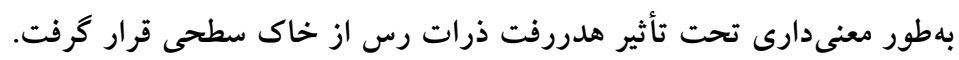

وازههاى كليدى: توزيع اندازه ذرات، خصوصيات خاك، شيب جنوبى، شيب شمالى، فرسايش سطحى 
تأثير قرار مى دهند. بهطوركلى زمانى كـه درجـهـ شـيب افـزايش مقدمه

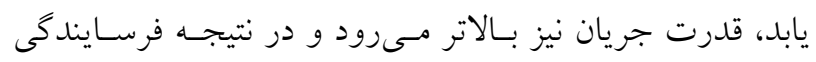

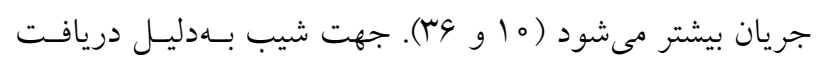

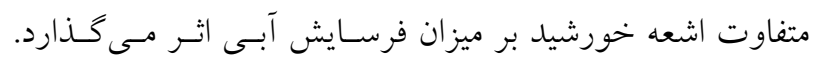

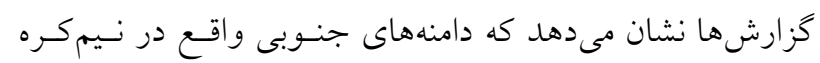

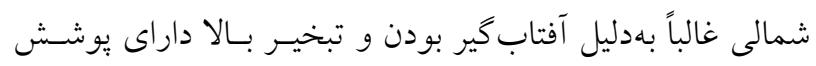

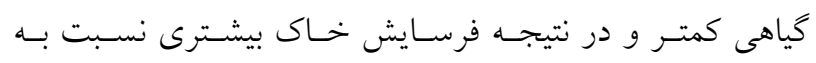

دامنهاى شمالى هستند (V و Y Y Y).

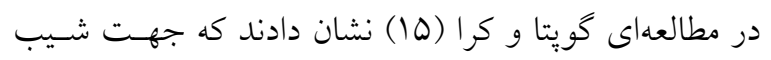

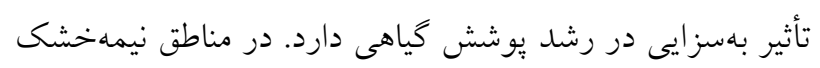

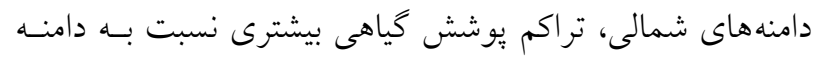

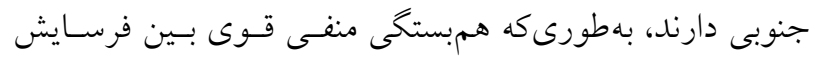

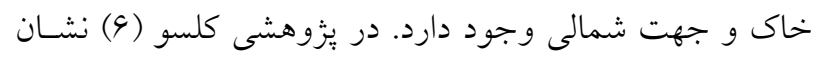

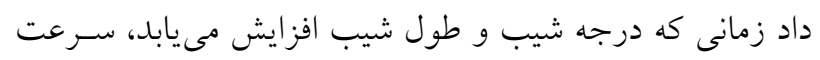

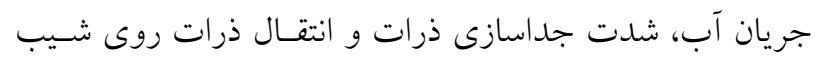

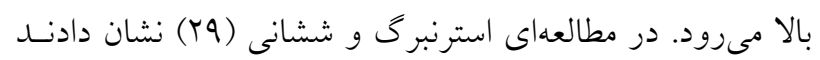

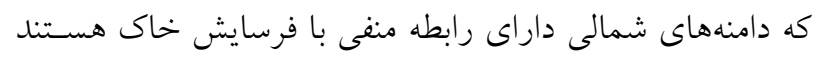

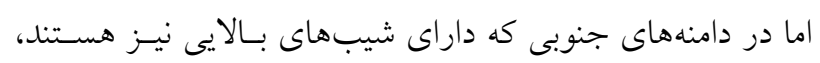

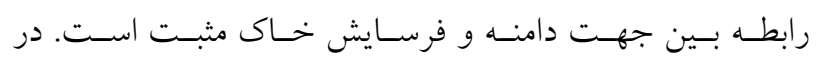

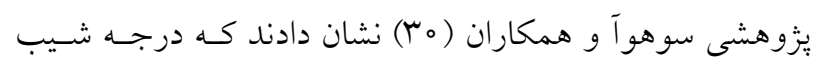

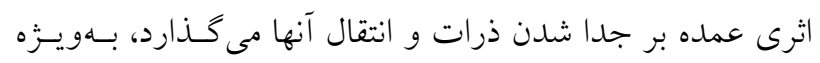

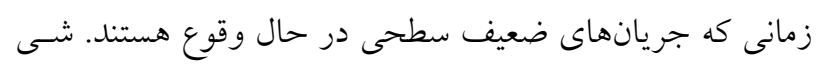

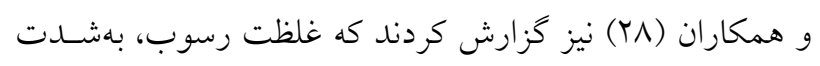

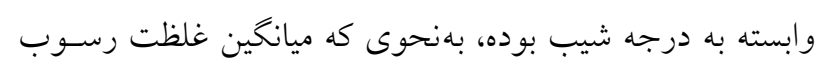

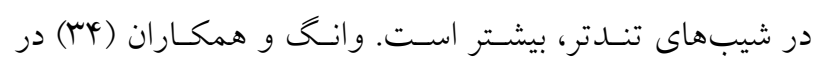

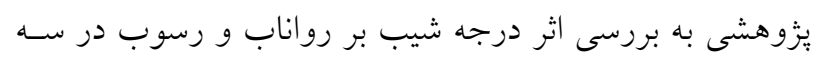

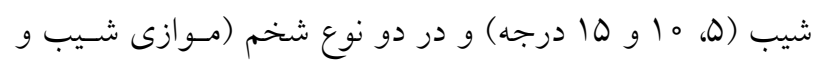

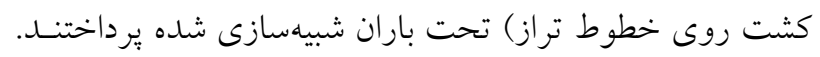

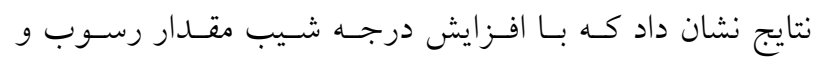

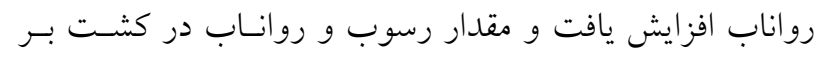

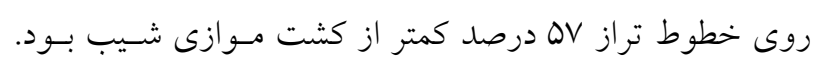

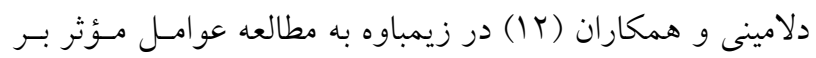

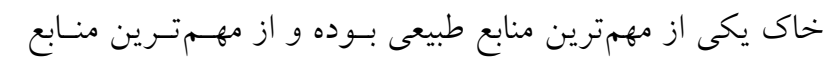

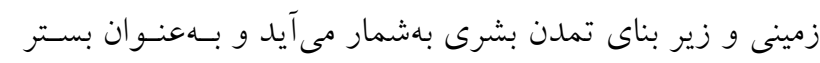

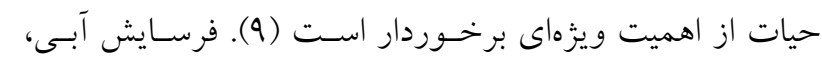

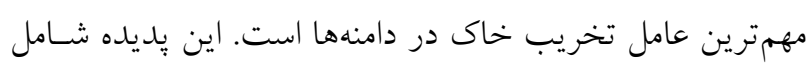

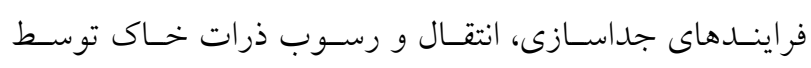

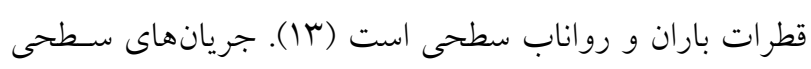

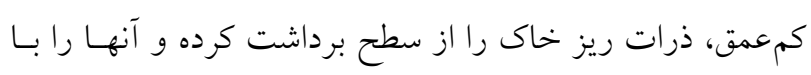

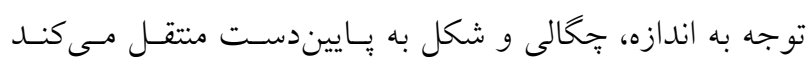

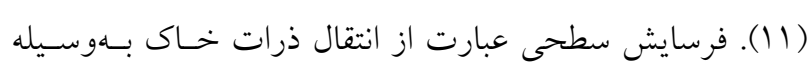

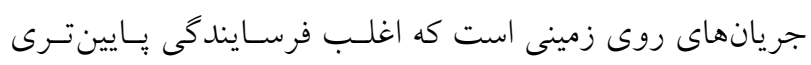

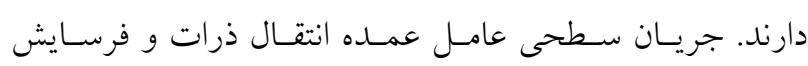

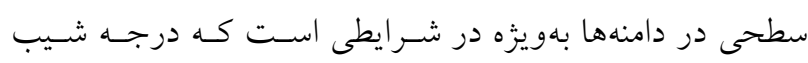

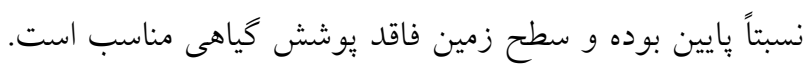

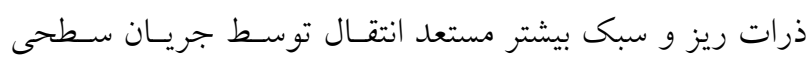

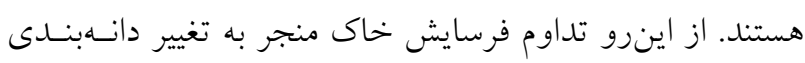

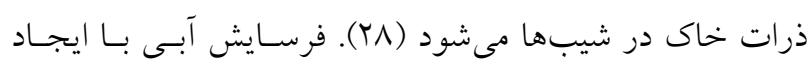

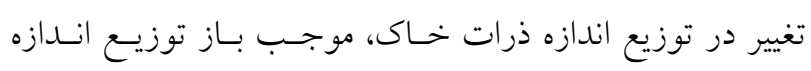
ذرات موجود در لايه سطحى خاك مىشود و مىتوانسد بـهـور

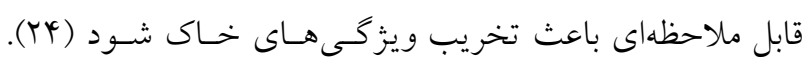

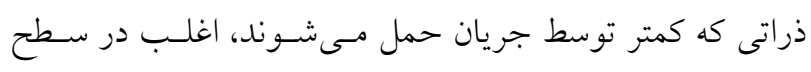

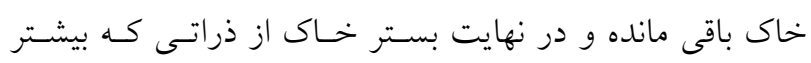
حمل شدهاند، تخليه مىشود.

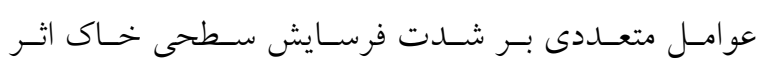

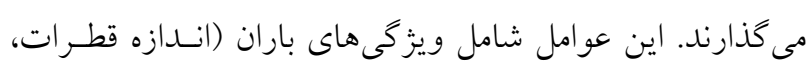

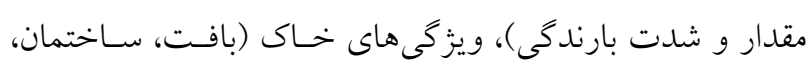

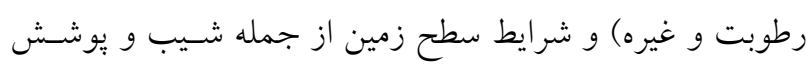

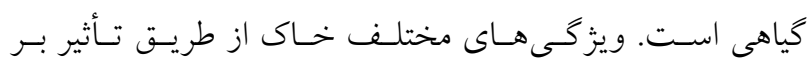

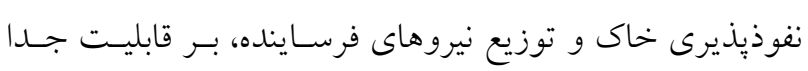

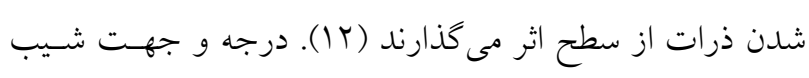

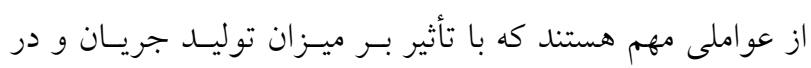

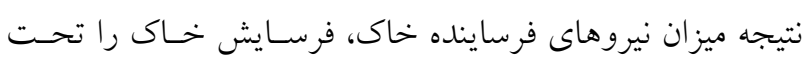


خاك در دامنه نقشى اساسى در تغييريذيرى توزيع انـدازه ذرات

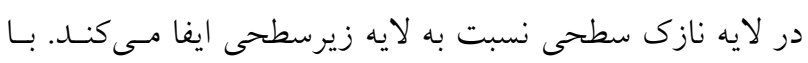
توجه به اهميت درجه و جهت شيب در فرسايش آبسى و تغييـر

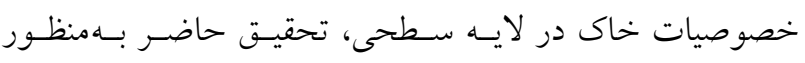

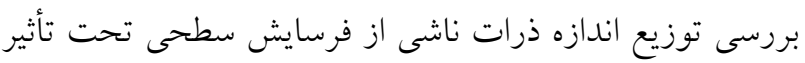
درجه و جهت شيب در منطقه نيمه خشك انجام كرفت.

\section{مواد و روشها - ماد

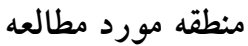

منطقه مورد مطالعه شامل تِههايى با يوشش كياهى ضعيف بـود كه در غرب استان زنجـان در يبرامـون روسـتاى يـاميجى در به

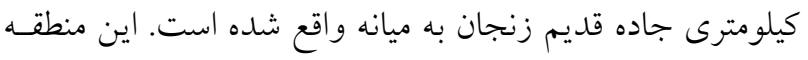
در محدوده جغرافيايى از "ها ا

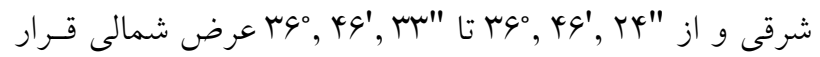

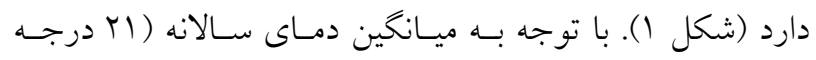

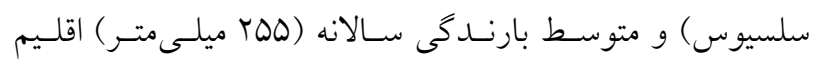

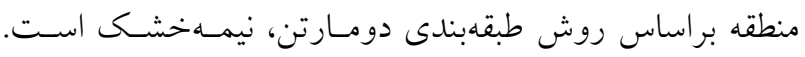

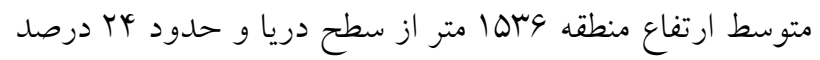

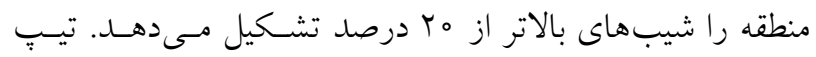

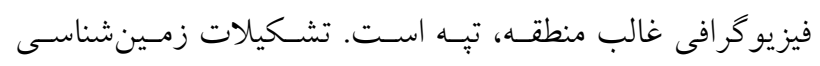

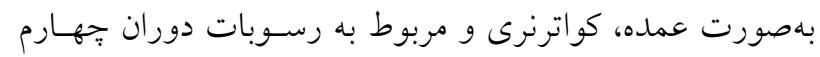

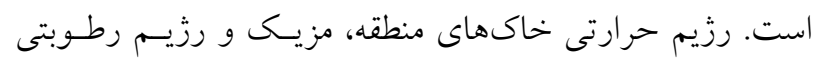

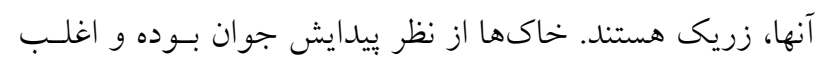

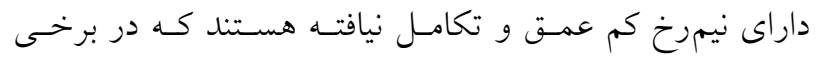
قسمتها بر روى طبقه آهكى قرار گرفته است (Y). ايسن نتساج

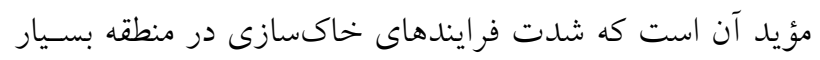
ضعيف است. گونههاى گيـاهى درمنـه (Artemisia) و خارشـتر از كونسههـاى غالـب كيـاهى در منطقـهـ هستند. اين منطقه تحت تأثير فرسايش سطحى قرار دارد. بروز

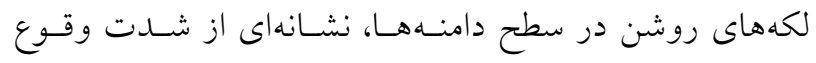
جنين فرسايشى در منطقه است. شكل (Y- الـف) نمونسهاى از داز

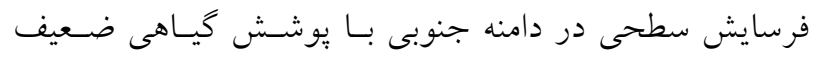

فرسايش سطحى در زمينهاى شيبدار يرداختند و بـراى انجـام

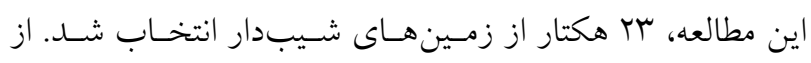

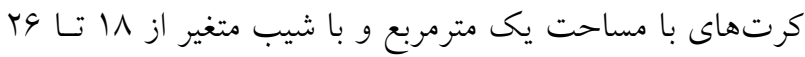

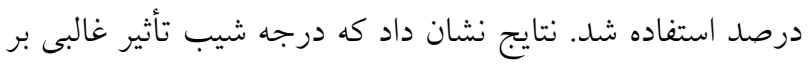
فرسايش سطحى خاك كذاشت و موجب افزايش تلفـات خـاك

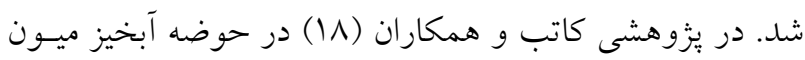

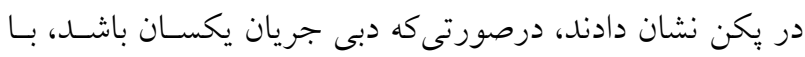

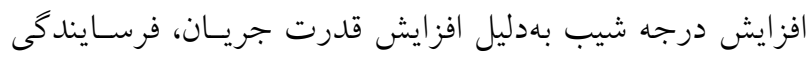

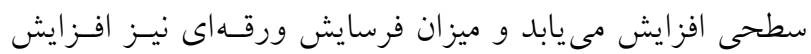

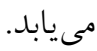
دامنههاى مرتعى واقع در مناطق نيمه خشـى اغلـب يوشـش كياهى ضعيفى دارد و بهدليل ضعف محتواى ماده آلى، بإيـارى ساختمان خاك بايين است (YT). تحت ايسـ شـرايط، خـاكهـا حساس به فرايندهايى ماننــ ضـربه قطـرات بـاران (ياشـمان) و

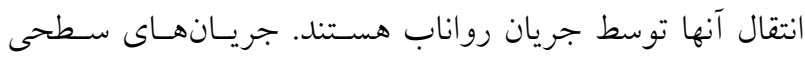

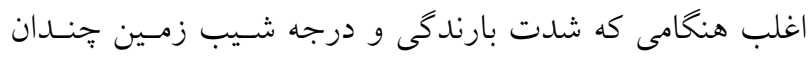

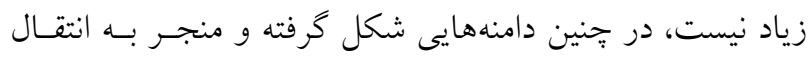

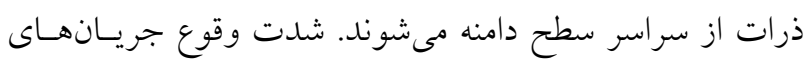

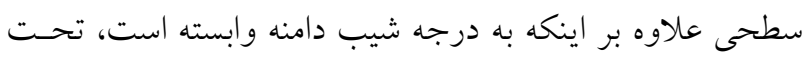

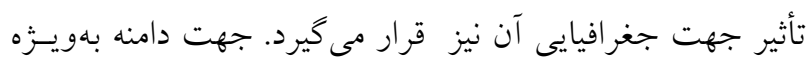

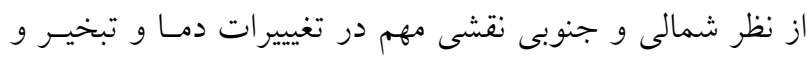

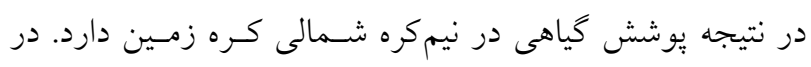

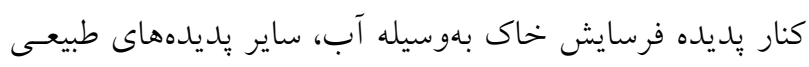

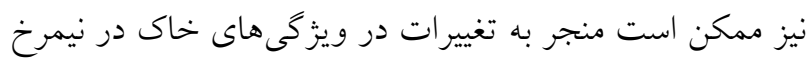

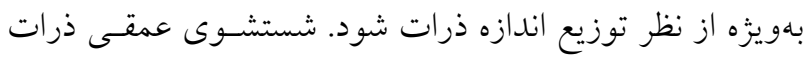

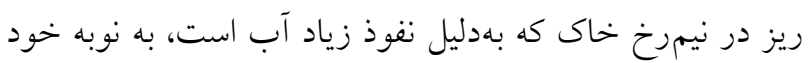

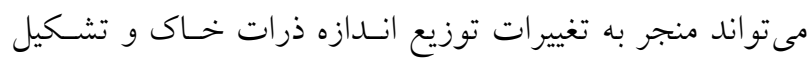

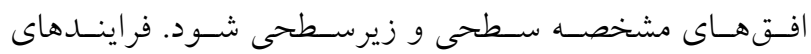

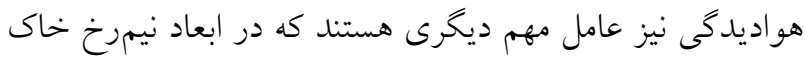
مى توانند منجر به تغيير ويزگى هاى خاك از مو اد مادرى و ظهور

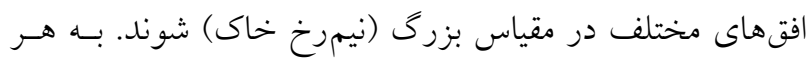

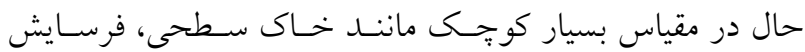




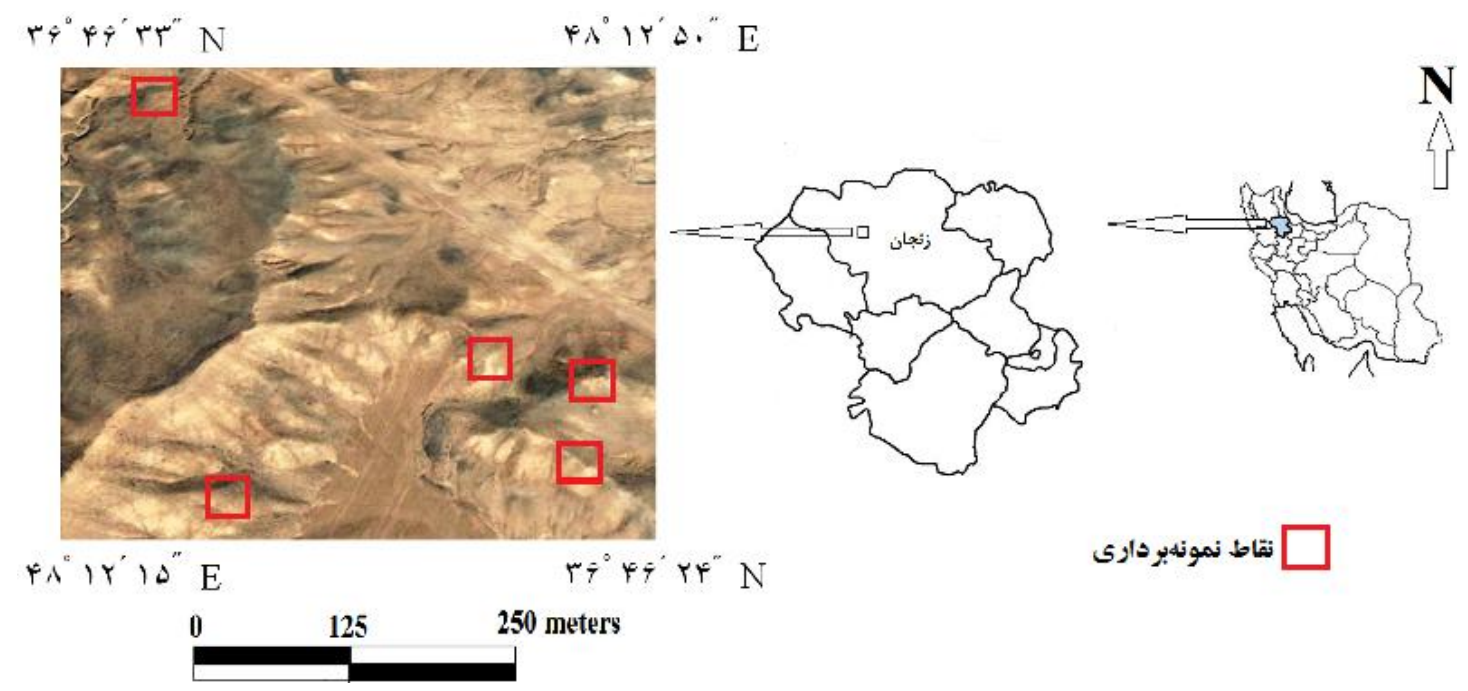

شكل 1. موقعيت منطقه مطالعاتى بر روى نقشه ايران و تصوير ماهو ارهاى

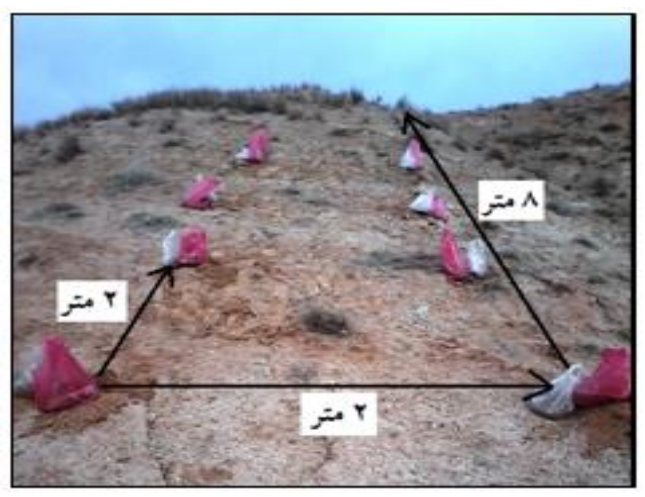

(ب)

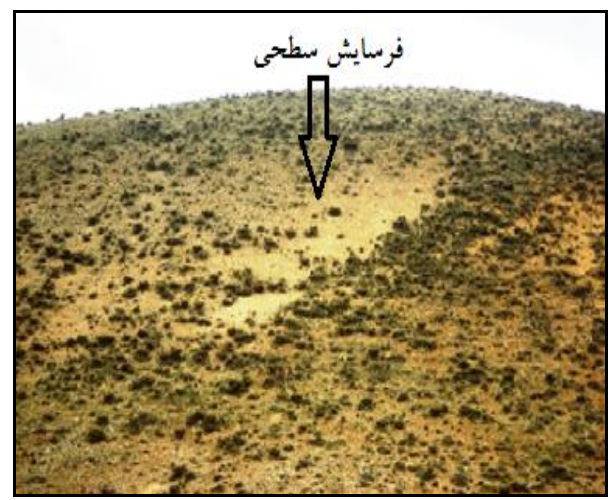

(الف)

شكل r. الف) نمايى از فرسايش سطحى در دامنه جنوبى و ب) موقعيت نقاط نمونهبردارى خاك در طول دامنه

تحت جر اى دام قرار بخيرند. دامنهاى شمالى داراى شيبهـاى

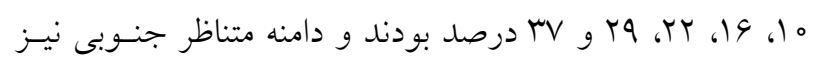

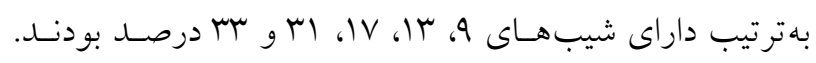

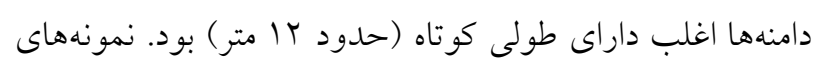

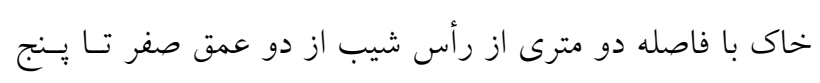

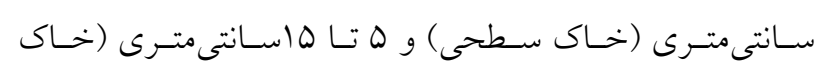

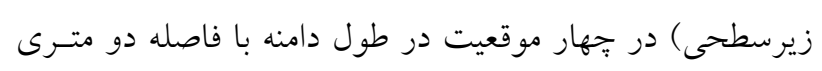

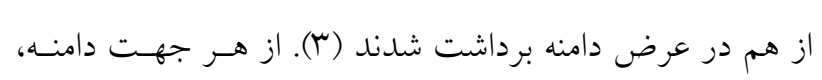

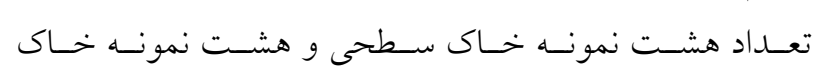

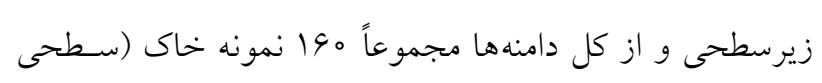

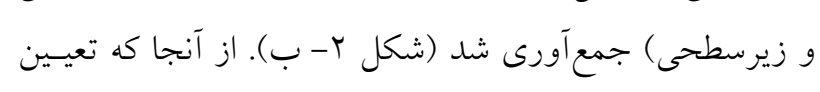

را نشان مىدهد. در منطقه مطالعاتى در كنـار فرسـايش سطحى

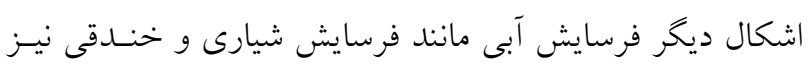
قابل مشاهده است.

نمونهبردارى و تجزيه خاك دامنهها

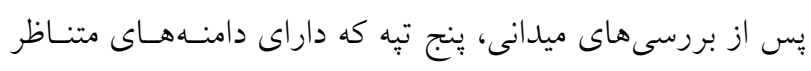

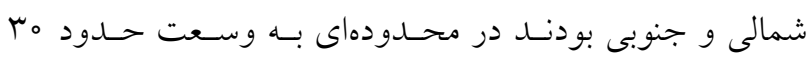
هكتار انتخاب شدند. ارتفاع نقاط از سطح آبهاى بـ آزاد در ايسن

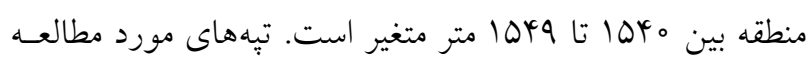

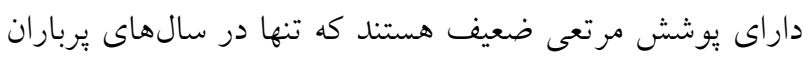

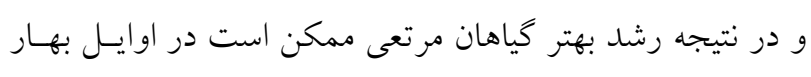


ابعاد بزرگ است، لزوم بهرهمندى از روش ساده و سـريع بـراى

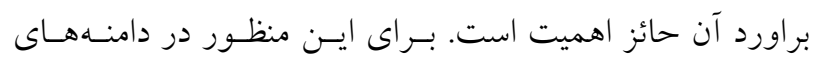

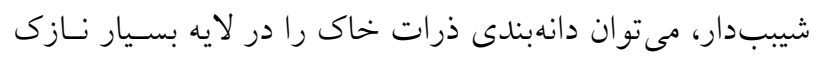

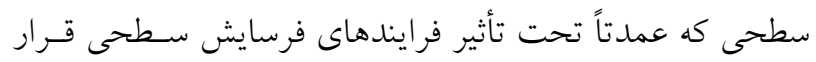

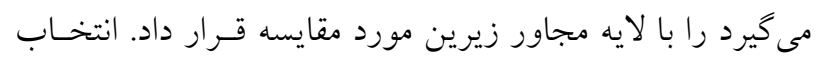

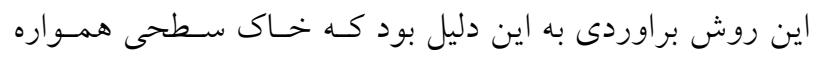

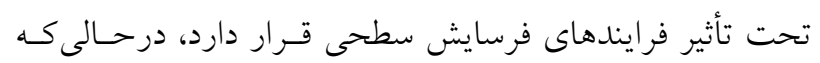

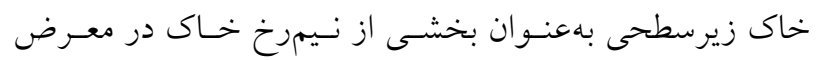

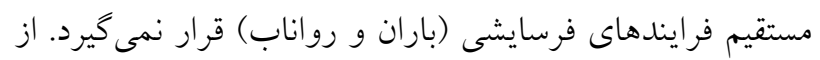

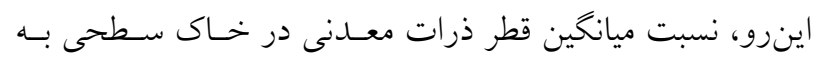

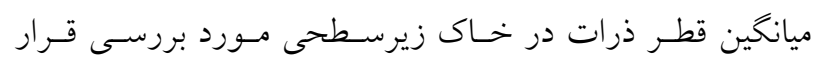

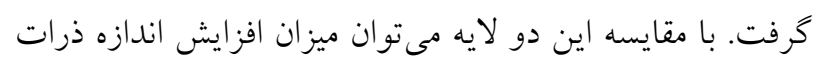

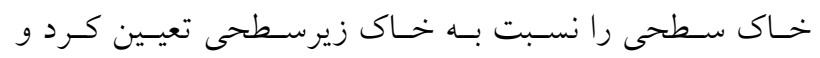

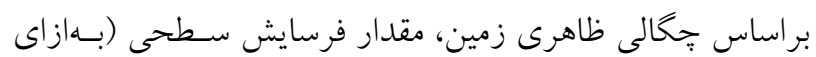

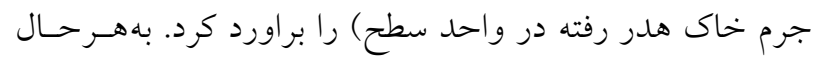

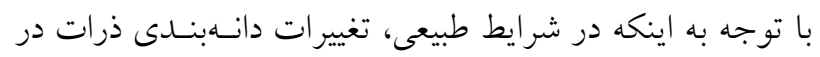
خاك سطحى نسبت به خاك زيرسطحى در يـك دامنه در ابعـاد

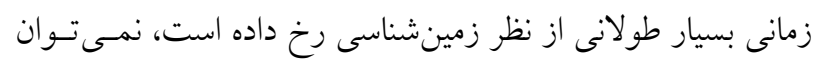

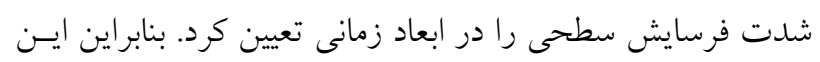

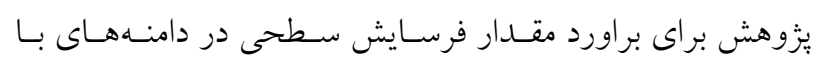

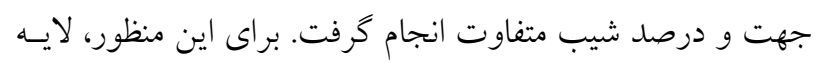
نازى خاك سطحى (صفر تا ه سانتىمتر) و لايه همجـوار زيـرين

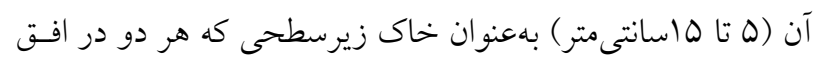

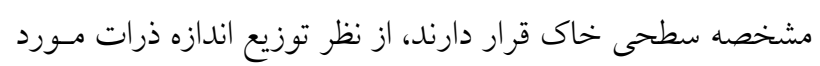

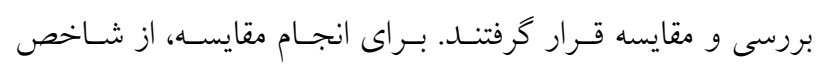

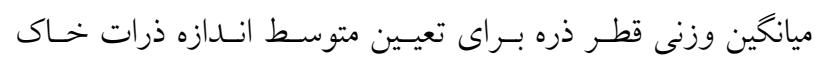
سطحى و خاك زيرسطحى استفاده شد (4)): $\operatorname{MWDp}=\operatorname{Sand} \times \frac{(r+\circ / \circ \Delta)}{r}+\operatorname{Silt} \times \frac{(\circ / \circ \Delta+\circ / \circ \circ r)}{r}+$

Clay $\times \frac{(0 / 00 r+0)}{r}$

Surface erosion rate $=\mathrm{MWDp}_{(())} / \mathrm{MWDp}_{(r)}$
فرسايش سطحى در شرايط طبيعى كارى دشوار اسـت، انتخـاب

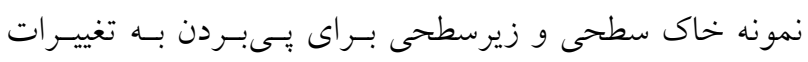

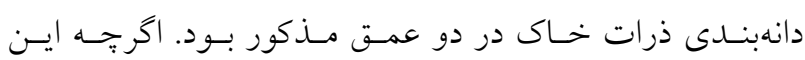

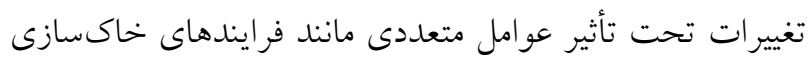

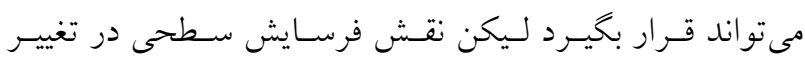

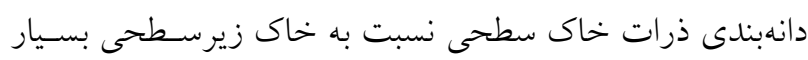

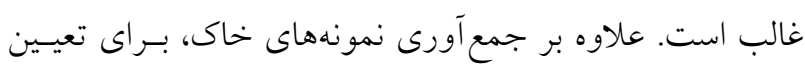

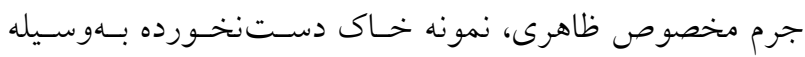

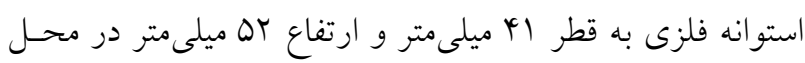
نمونهبردارى برداشت شد (Yo (Y).

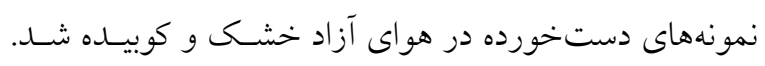

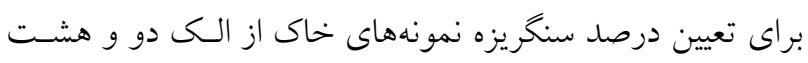

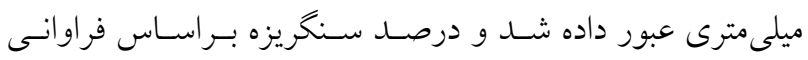
ذرات با قطر دو تا هشت ميلىمتر در نمونه خاك سـطحى تعيسين

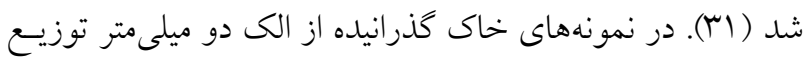

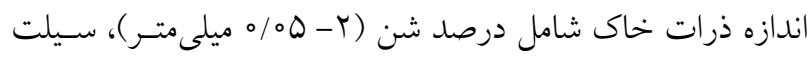

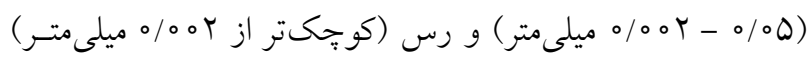

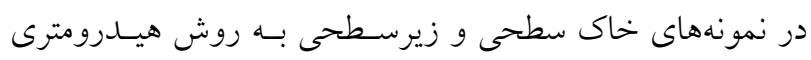

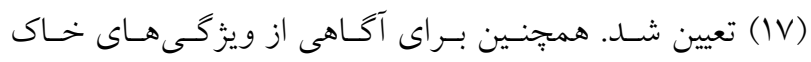

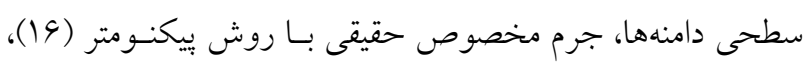

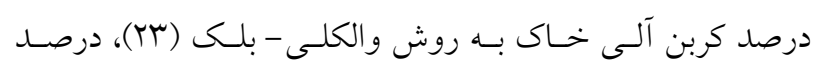

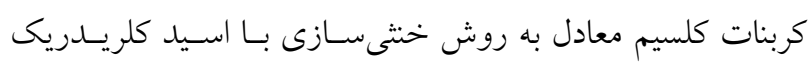

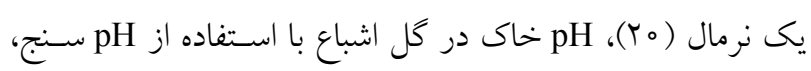

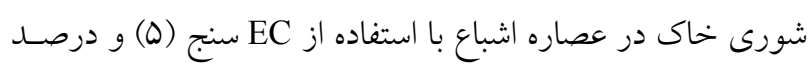

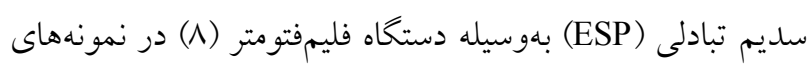
خاك سطحى تعيين شدند.

براورد مقدار فرسايش سطحى خاك

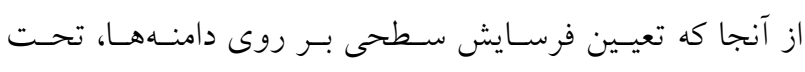

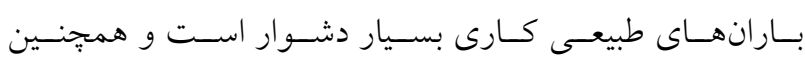

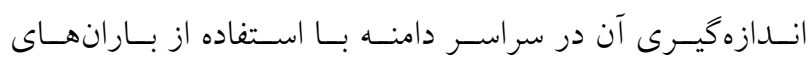

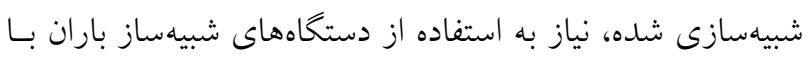




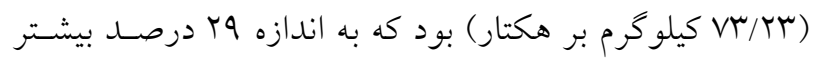

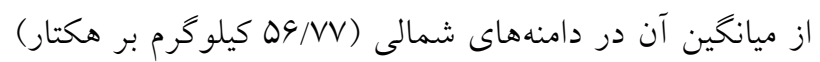

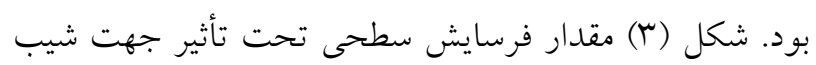

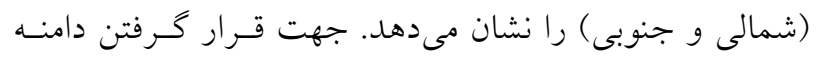

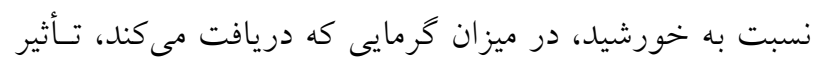

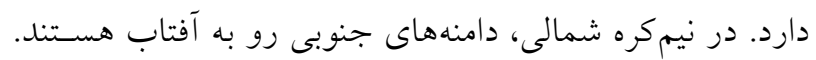

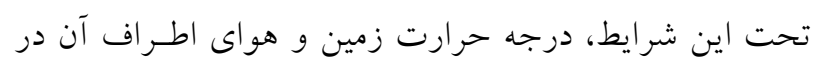

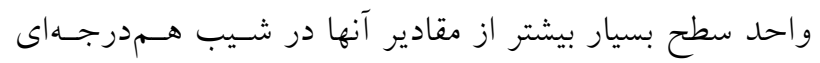

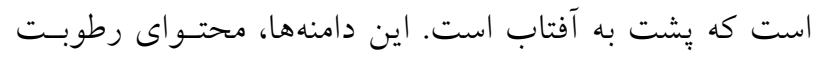

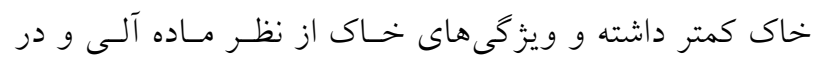

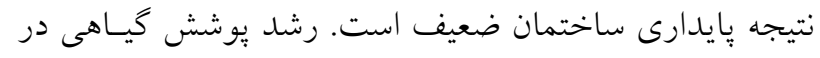

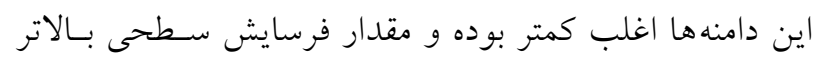

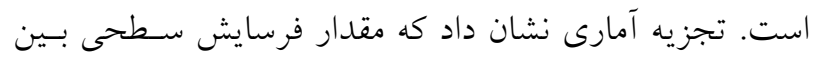
دو دامنه جنسوبى و شـمالى تفـاوت معنسى دار (p/0/00) دارد

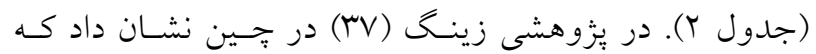

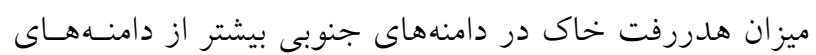

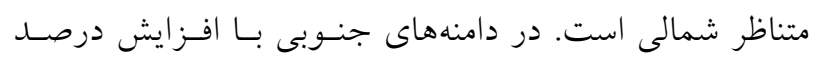

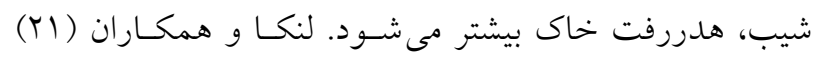

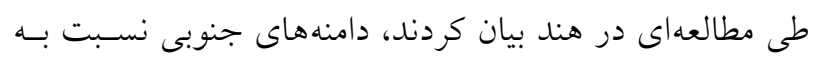

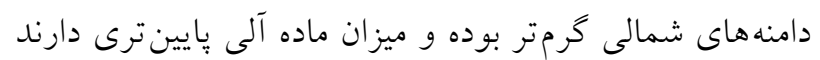

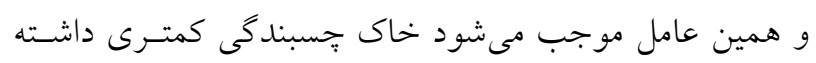
باشد.

بررسى تغييرات فرسايش سـطحى بـين درجـات مختلـف شيب نشان داد كه مقــدار فرسـايش سـطحى در هـر دو دامنـه

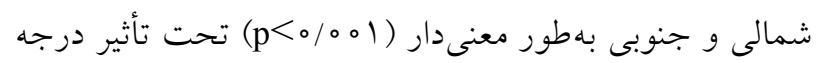

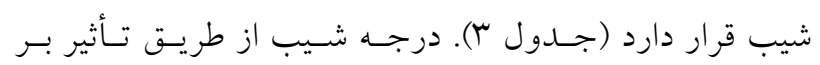

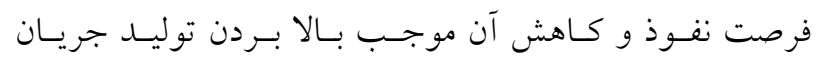

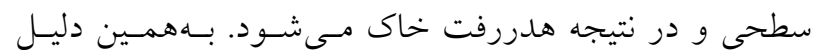
ميزان فرسايش خاك در دامنههايى با شيب بالا افـزايش نشـان داد. با افزايش درصد شـيب بـهدليـل افزايش قـــرت جريـان شدت جدا شدن ذرات بـرروى شسيب بـالا رفتـه و هـدررفت

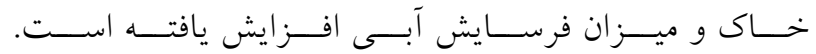

كه در آن: شن، سيلت و رس برحسب درصد وزنسى و MWDp ميانخين قطر ذرات خاك (mm) است.

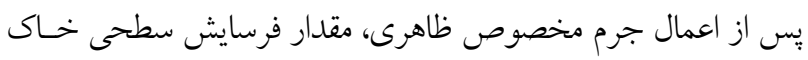

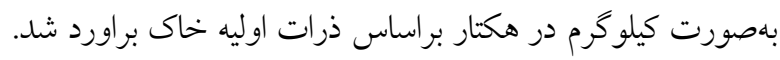

\section{تجزيه و تحليل دادهها}

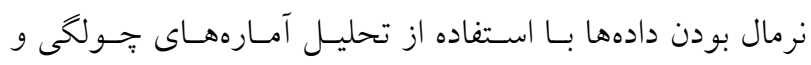

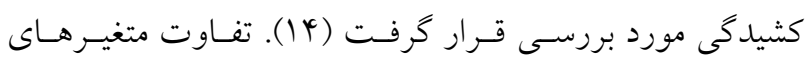
تحت بررسى (مقدار فرسايش سطحى و دانهبندى ذرات خـاك) بين درجههاى شيب بهروش تجزيه واريانس با استفاده از آزمون

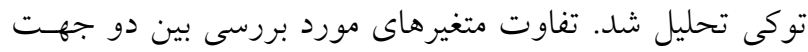

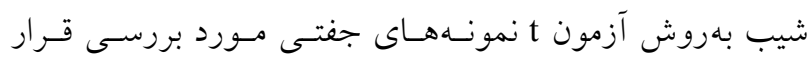

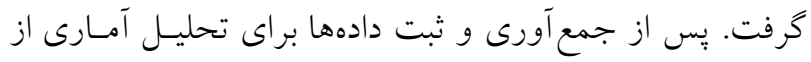

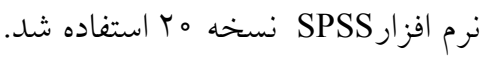

\section{نتايج و بحث}

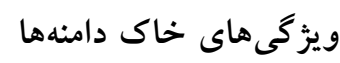

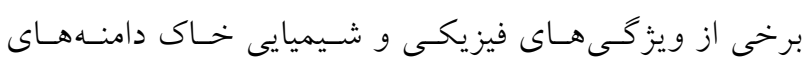

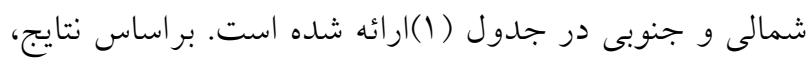
بافت غالب خاك دامنههاى شمالى، لوم رسى بود. خـاك داك ايسن

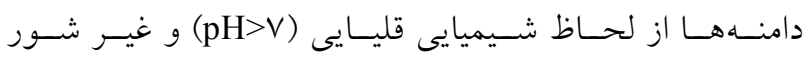

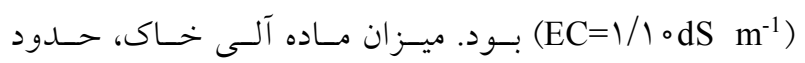

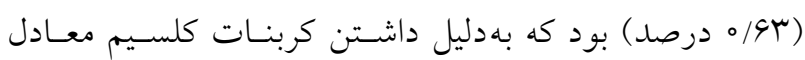

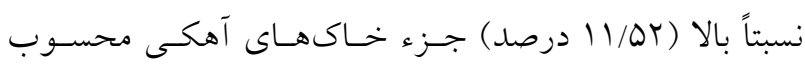
مىشود. در دامنهاى جنوبى متناظر نيز بافت غالب خـاكهـا،

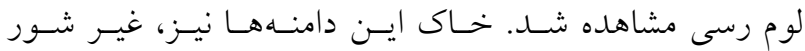

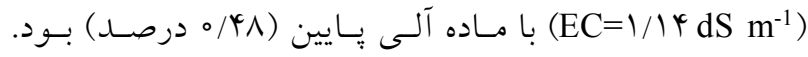

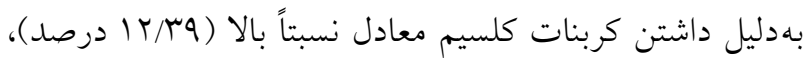

$$
\text { خاى اين دامنهها نيز آهكى بود. }
$$

تغييرات مقدار فرسايش سطحى در دامنهها

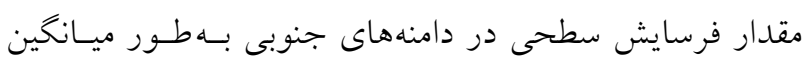


جدول ا. ويزّكىهاى فيزيكى و شيميايى خاك در دامنهاى شمالى و جنوبى

\begin{tabular}{|c|c|c|}
\hline دامنه جنوبى & دامنه شمالى & $<1$. \\
\hline انحر اف معيار 土 ميانخين & انحراف معيار土 ميانخين & o \\
\hline$r r / \mu q \pm 1 r / \| r$ & $\| / \Psi \wedge \pm Y \Psi / \mu \mid$ & شن (\%) \\
\hline$Y \circ / 0 Y^{r} \pm \mid r / q r$ & $9 / \mu 1 \pm r r / V I$ & سيلت (\%) \\
\hline$r V / \Delta Q \pm 1 r / \Lambda q$ & $r \mid / 99 \pm 1 r / 91$ & رس (٪) \\
\hline$V / 9 V \pm 9 / \mu V$ & $q / 4 V \pm q / 1 T$ & سنخريزه (\%) \\
\hline $1 / 0 \wedge \pm 0 / 19$ & $1 / 44 \pm 0 / / V$ & جرم مخصوص ظاهرى ( ${ }^{-3} \mathrm{~g} \mathrm{~cm}^{-3}$ \\
\hline V/VG $\pm 0 / 11$ & $V / N T \pm 0 / 11$ & \\
\hline $1 / / 4 \pm 0 / 4 \varphi$ & $1 / 1 \circ \pm \circ / \mu \Lambda$ & هدايت الكتريكى (dS m-1) \\
\hline$\circ / 4 \Lambda \pm \circ / \vee V$ & $0 / 9 \mu \pm 0 / \mu r$ & 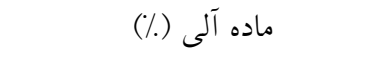 \\
\hline $1 r / r q \pm 1 / q r$ & $11 / 0 r \pm 1 / 91$ & كربنات كلسيم معادل (.) \\
\hline
\end{tabular}

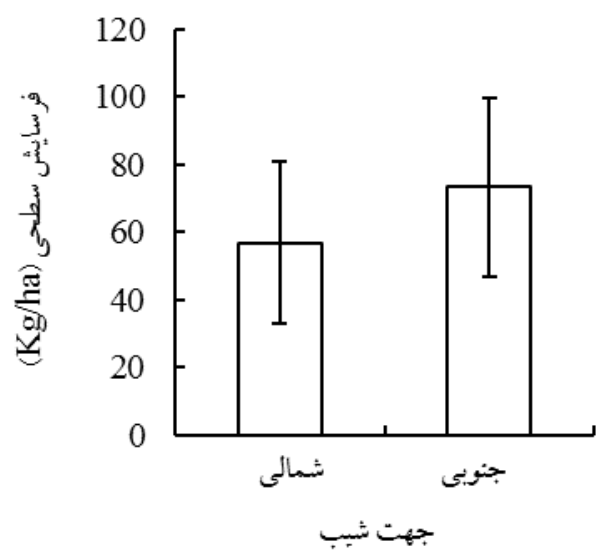

شكل r. مقدار فرسايش سطحى تحت تأثير جهت شيب

جدول r. نتايج تجزيه واريانس تأثير جهت شيب بر فرسايش سطحى

\begin{tabular}{|c|c|c|c|c|}
\hline معنى دارى & $\mathrm{t}$ & اختلاف ميانخين & درجه آزادى & منبع تغييرات \\
\hline$\circ / \circ \Delta$ & $1 / 99$ & $\mathrm{~T} / 9 \mathrm{~V}$ & VA & مقدار فرسايش سطحى \\
\hline
\end{tabular}

جدول r. تجزيه واريانس تأثير درجه شيب بر مقدار فرسايش سطحى در دو جهت شيب

\begin{tabular}{|c|c|c|c|c|c|}
\hline $\mathrm{F}$ & مجموع مربعات & ميانخين مربعات & درجه آزادى & جهت شيب & منبع تغييرات \\
\hline $11 / 91^{* * *}$ & $11 / \Delta \Lambda$ & $r / \wedge 9$ & r & شمالى & \\
\hline$Y \backslash / \Delta \wedge^{* * *}$ & YT/AD & $Q / V I$ & r & جنوبى & سطحى \\
\hline
\end{tabular}


تغييرات توزيع اندازه ذرات خاك تحت تأثير جهت دامنه

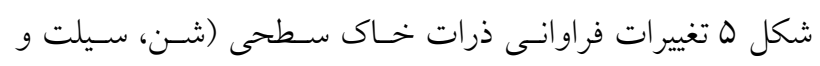

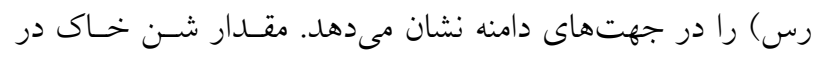

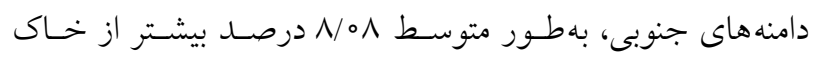

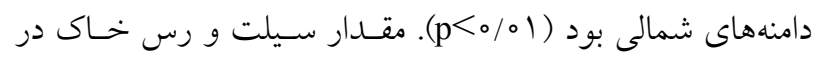

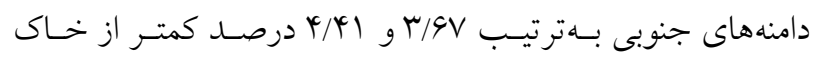

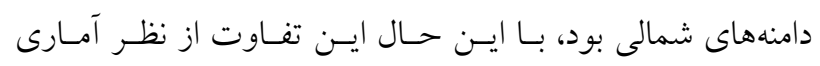

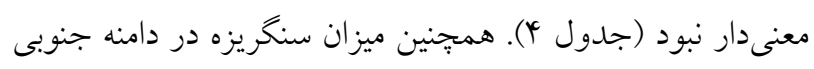

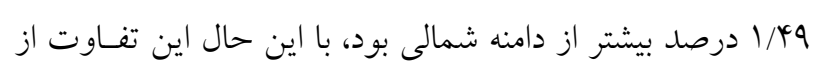

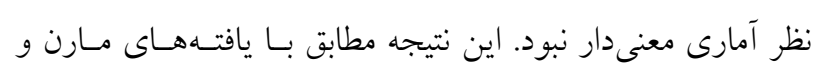

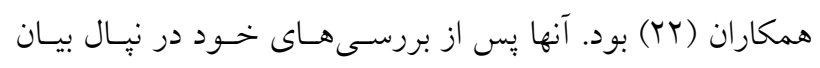

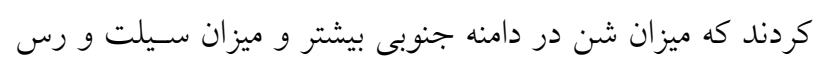

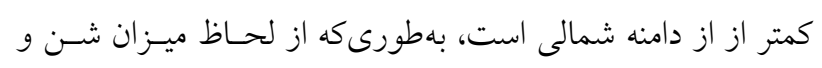

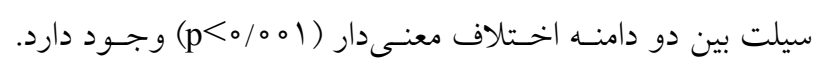

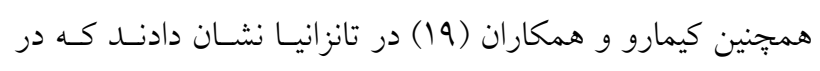

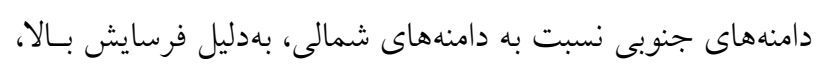

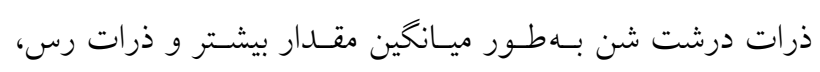

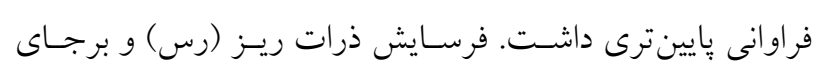

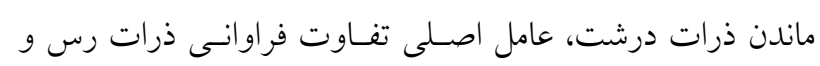

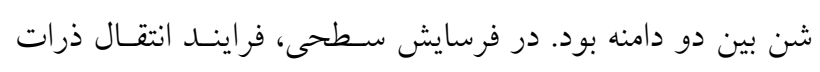

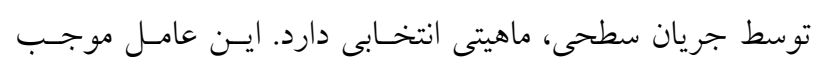

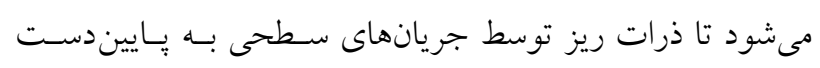

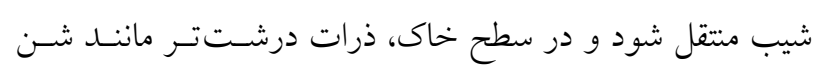

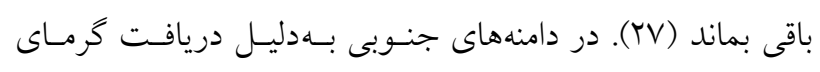

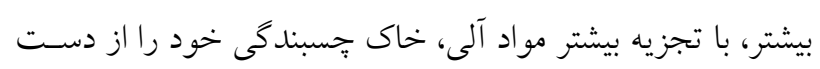

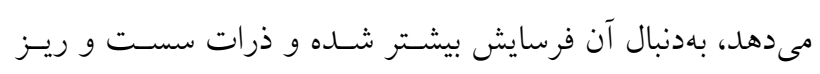

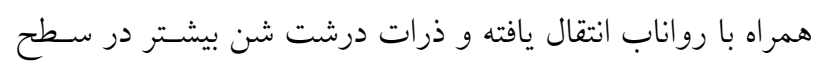

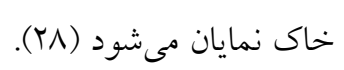

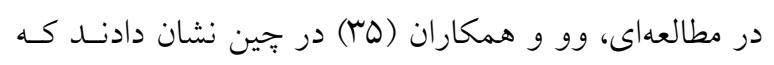

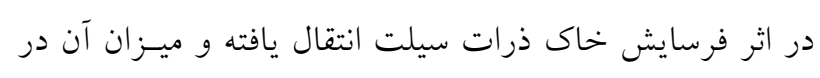
سطح خاك در نقاط فرسـايشيافتـه، كـاهش يافـت همبجنسين

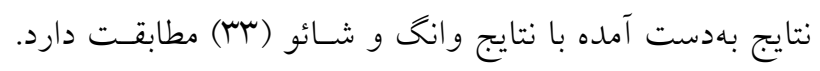

علت اصلى فرسايش سطحى در دامنهاى شمالى با افزايش شيب،

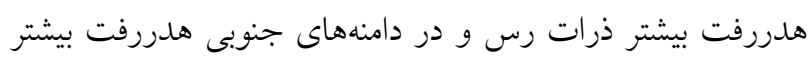

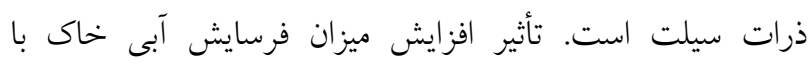
افزايش درصد شيب با نتايج زينخ (YV) مطابقت دارد.

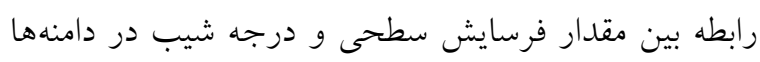

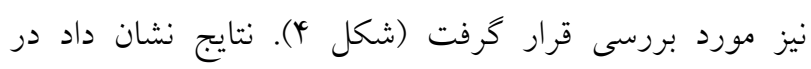

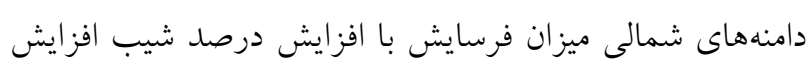

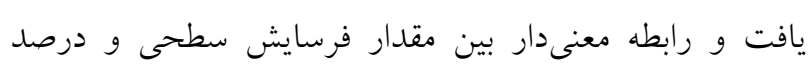

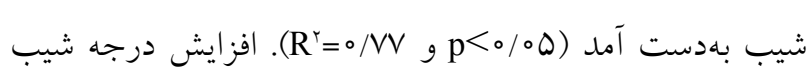
در دامنههاى جنوبى نيز موجب افزايش مقدار فرسايش سطحى (مله

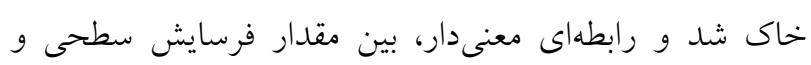

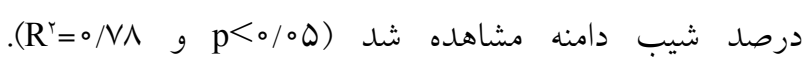
نتايج حاصله با يافتهاى زارغخورميزى و همكاران (1)

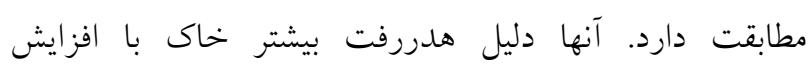
درصد شيب را كاهش مقاومت خاك سطحى بيان كردند. يافتهاى

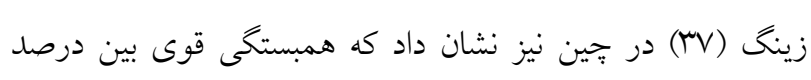

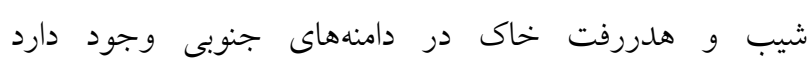

$$
\text { . }\left(\mathrm{R}^{\mathrm{r}}=0 / 94 \mathrm{q}, \mathrm{p}<0 / 01\right)
$$

مطابق با معادلات ارائه شده بين فرسايش سطحى و شـيب

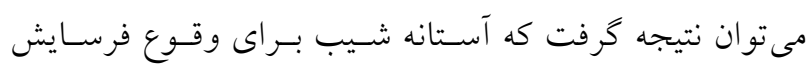

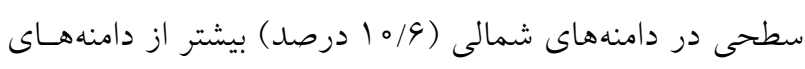

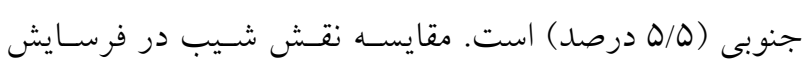
سطحى در دامنه هاى شمالى و جنوبى نشان مىدهد كه اهميت

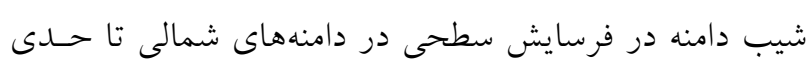

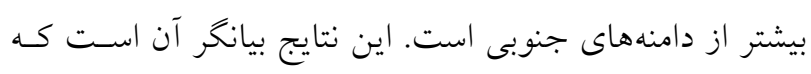

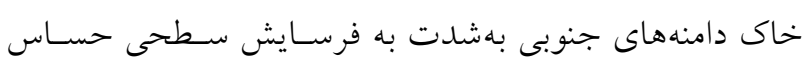

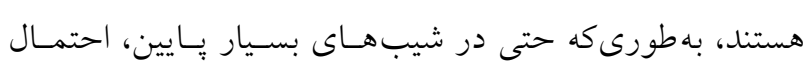

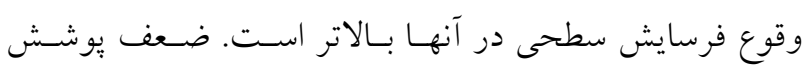

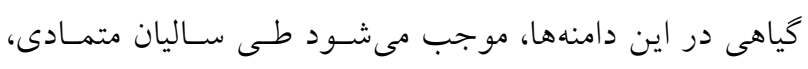

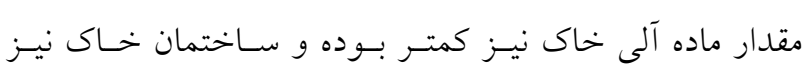

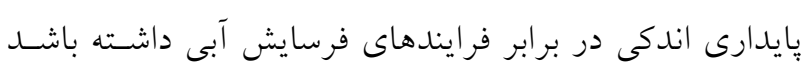



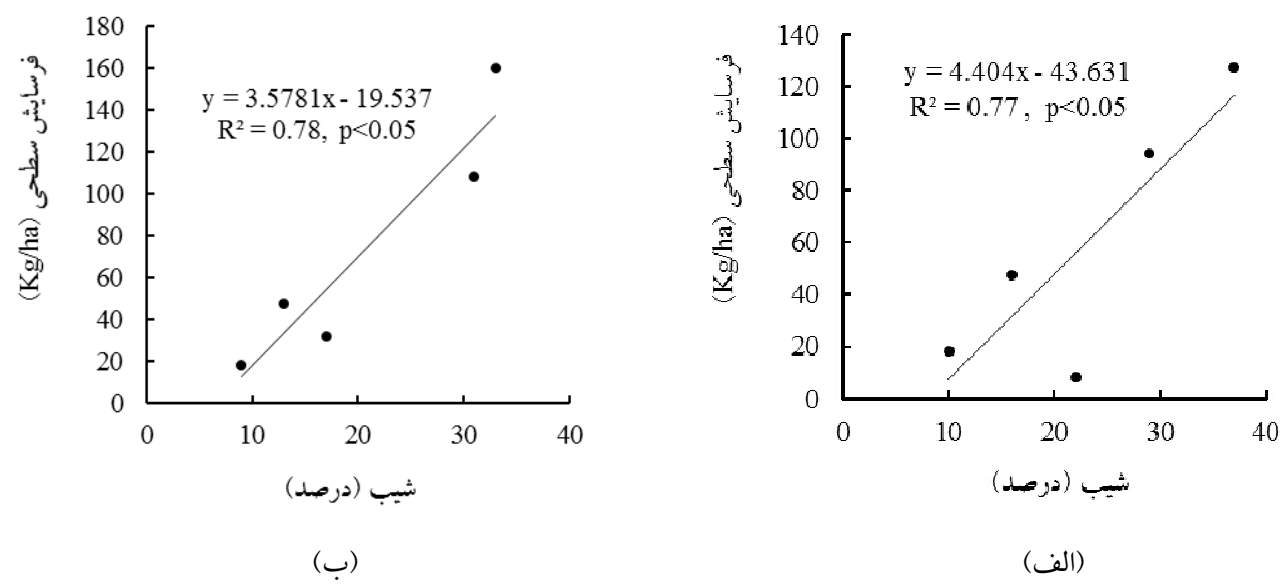

شكل f. الف) رابطه بين مقدار فرسايش سطحى و درصد شيب در الف) دامنههاى شمالى و ب) دامنههاى جنوبى (ب)
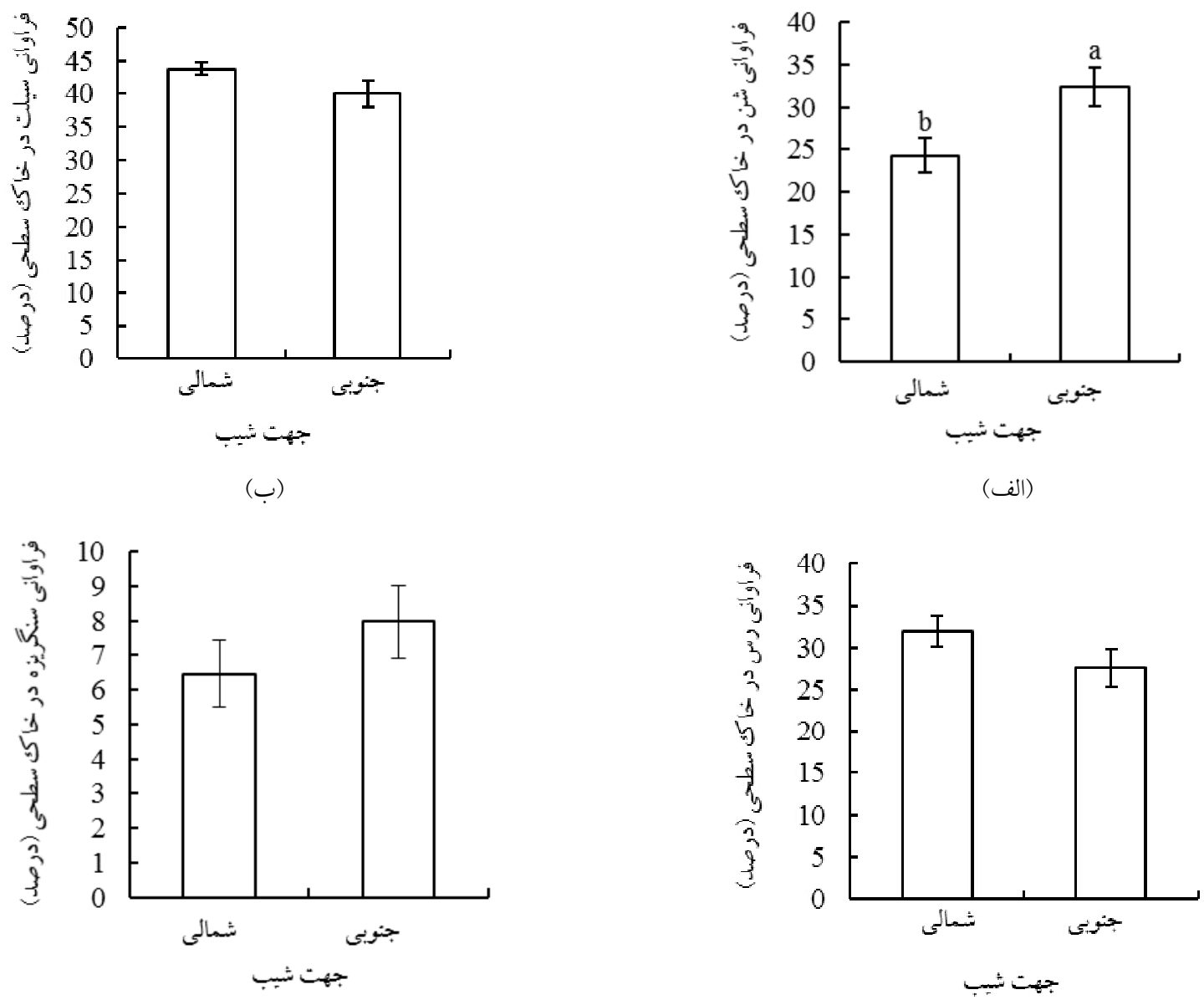

(2)

(ج)

شكل ه. اثر جهت شيب بر فراوانى ذرات خاك سطحى: الف)شن، ب) سيلت، ج) رس و د) سنكريزه 


\begin{tabular}{|c|c|c|c|c|}
\hline معنى دارى & $\mathrm{t}$ & اختلاف ميانخين & درجه آزادى & منبع تغييرات \\
\hline $0 / 01$ & $T / \Psi A$ & $V / 9 T$ & VA & شن \\
\hline $0 / 19$ & $1 / \pi 9$ & $r / 90$ & VA & سيلت \\
\hline.$/ 19$ & - & V/qu & VA & رس \\
\hline $0 / Y 1$ & $1 / 49$ & $1 / 1$ & VA & سنخريزه \\
\hline
\end{tabular}

(R $=0 / 90$ g $p<0 / 01)$ يايدارى خاك روى سطح شيب كاهش مىيابد (YO). با توجه به نتايج مىتوان نتيجه كرفت كه علت اصلى فرسايش سـطى در دامنههاى شمالى با افزايش شيب، هدررفت بيشـتر ذرات رس و در دامنههاى جنوبى هدررفت بيشتر ذرات سيلت است.

\section{نتيجه گيرى}

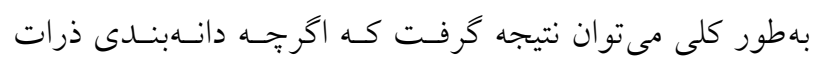
خاك سطحى تحت تأثير جهت شيب قرار مى كيرد اما اين عامل نقشى قابل توجه در مقدار فرسايش سـطحى در منطقـه نــدارد. درجه شيب بهطور قابل ملاحظهاى در كنار تغيير توزيـع انـدازه ذرات خاى سطحى، بر مقدار فرسايش سطحى نيز اثر مى گذارد.

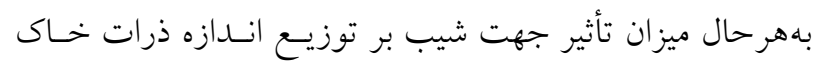

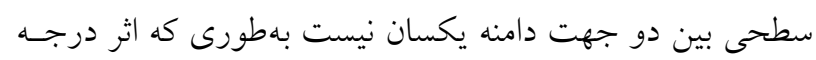
شيب بر مقدار فرسايش سطحى در دامنهــاى شـمالى بيشـتر از دامنههاى جنوبى اسـت. بررسسى فراوانسى ذرات خـاك بـين دو جهت دامنه نشان داد كه مجموع فراوانى ذرات شن و سـنخريزه و نيز مجموع فراوانى ذرات سيلت و رس بين دو جهـت دامنسه نشاندهنده وجود اختلاف معنى دار است. هدررفت بالاى ذرات ريز (سيلت و رس) از خاى سـطحى و بـر جـاى مانــن ذرات درشت، از دلايل بالا بودن ميزان شن و سنگريزه و يـايين بـودن ميزان سيلت و رس در دامنههاى جنوبى نسـبت بـه دامنـههـاى

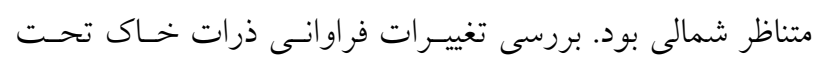
تأثير درصد شيب نشان داد كه تغييرات قابل تـوجهى بـين ميـزان شن در خاك سطحى و زيرسطحى بين دامنهاى شمالى و جنوبى
آنها نشان دادند كه ذرات سيلت داراى جسبند گى اندكى هسـتند و حساس بـه انتقـال هسـتند و زمـانى كـه در برابـر نيـروهـاى فرساينده قرار گيرند، بهآسانى منتقل مىشوند. انتقال ايسن ذرات در دامنههايى با شيب بالا بيشتر صورت مى گيرد. در دامنسهــاى جنوبى كه داراى شيبهاى تند هسـتند، بـارانهـايى كـه شـدات يايين اما مدت طولانى دارنــ، شـرايط انتقـال سـيلت را فـراهم مى آورند. بنابر عقيده بين (Y) فرسايش يذيرى بـالاى سـيلت در

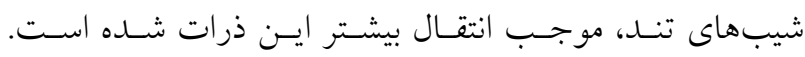
براساس نتايج حاصله رابطه بين درصـد شسيب و ميـزان سـيلت منفى بوده كه موجب شده تا ميزان سيلت در دامنههـاى جنـوبى نسبت به دامنههاى متناظر شمالى، مقـدار كمتـرى داشـته باشـــ. افزايش ميـزان شـن و كـاهش ميـزان ذرات ريـز در دامنـههـاى

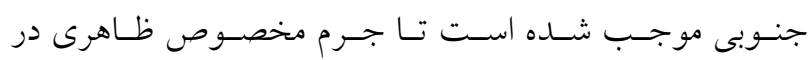
دامنههاى جنوبى بيشتر از دامنهاى متناظر شمالى باشد.

تغييرات توزيع اندازه ذرات خاك تحت تأثير شيب دامنه شكل 9 نسبت دانسهبنـدى ذرات شـن، سـيلت و رس در خـاك سطحى به خاى زيرسطحى، تحـت تـأثير درجـه شـيب، در دو جهت شيب را نشان مىدهد. براساس نتايج، نسـبت دانسهبندى ذرات شن سطح بــه زيسر سـطح، بـا افـزايش درصــ شـيب در دامنه هاى شمالى و جنوبى افزايش قابل تـوجهى را نشـان نـداد. نسـبت دانسهبنـدى ذرات سـيلت سـطح بـه زيرسـطح تنهـا در دامنسههــاى جنـوبى تحــت تـأثير شـيب دامنسه قــرار خرفـت

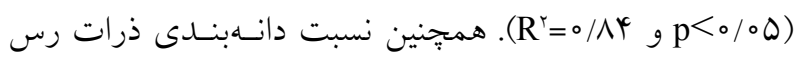
سطح به زيرسطح نيز تنها در دامنسهــاى شـمالى كـاهش يافـت 


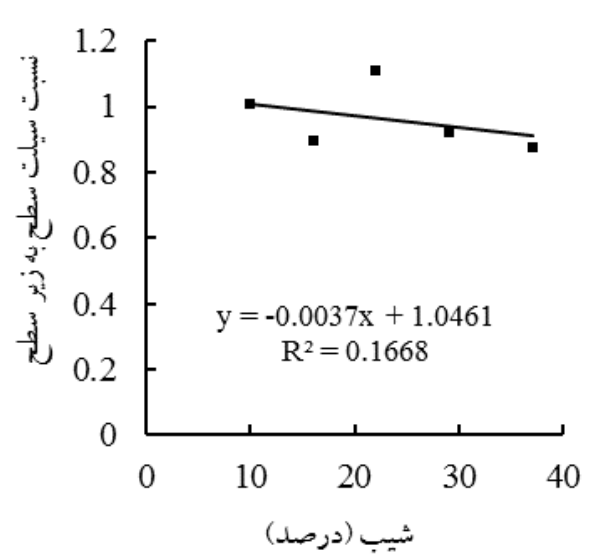

(ب)

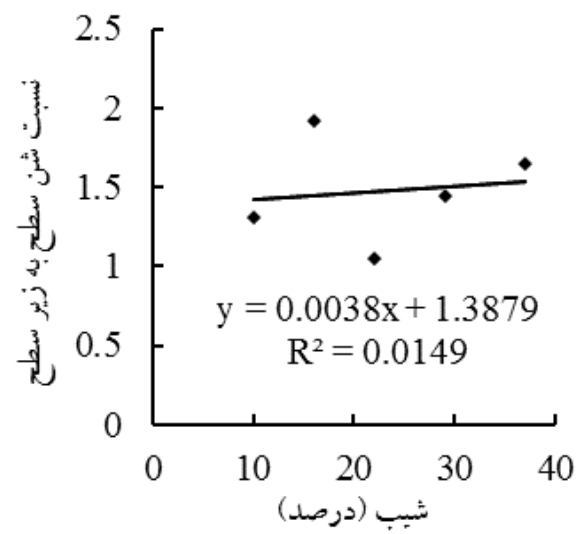

(الف)
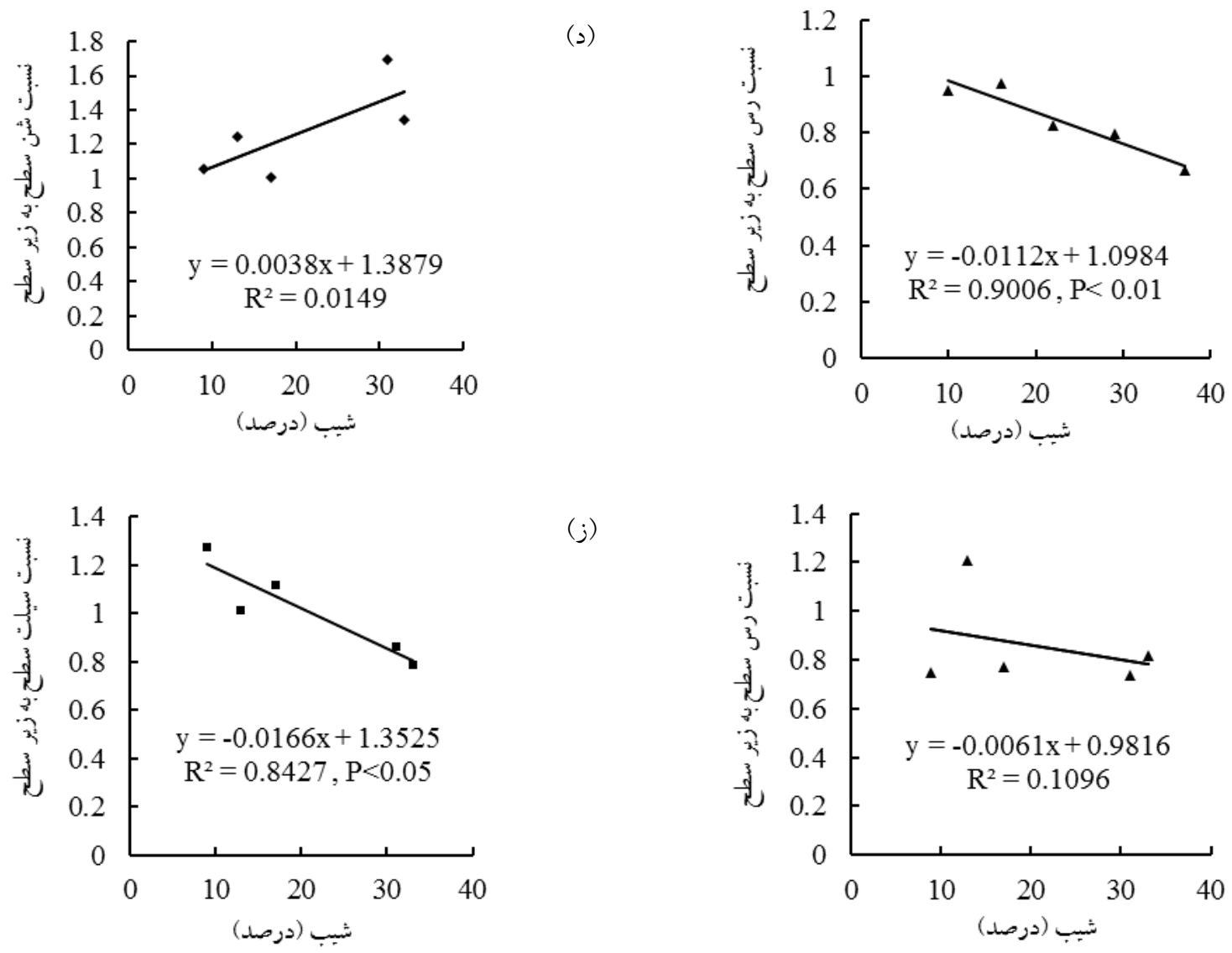

شكل 9. رابطه بين درصد شيب دامنه و نسبت دانهبندى ذرات سطح به زيرسطح در دامنههاى شمالى؛ الف) شن، ب) سيلت، ج) رس و در دامنه هاى جنوبى: د) شن ، ر) سيلت، ز) رس

يافت. بهطـوركلـى ايـن يـزوهش نشـان داد كـه در دامنـهــاى

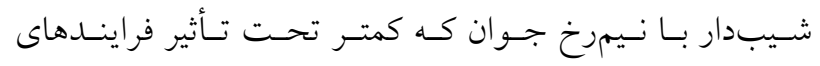

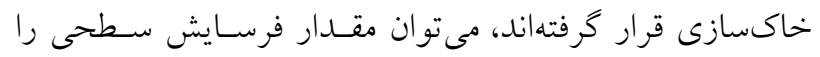

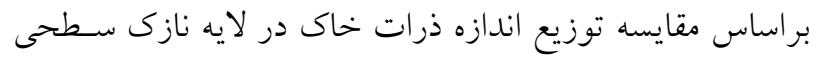

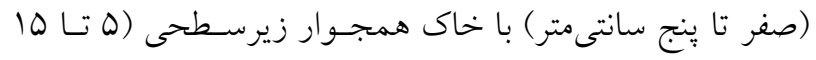

وجود ندارد. با اين وجود در دامنههاى جنوبى نسبت دانهبنــى ذرات سيلت سطح به زيرسطح تحت تـأثير درصسد شـيب قـر فرار

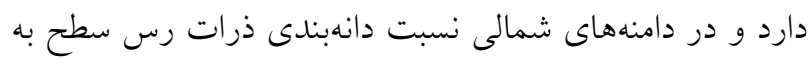

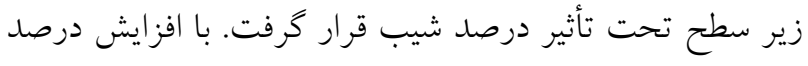

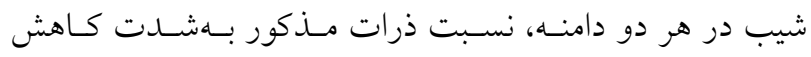




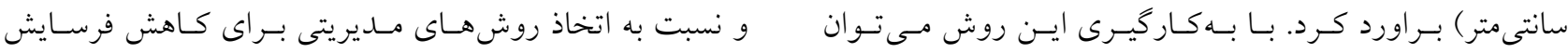

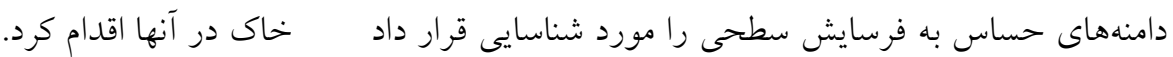

$$
\begin{aligned}
& \text { منابع مورد استفاده } \\
& \text { ا. زارعخورميزى، م.، ع. نجفىنزاد، ن. نورا وع. كاويان. •وبا. اثر شيب و خصوصيات خاك بر رواناب و هدررفت خاك با استفاده }
\end{aligned}
$$

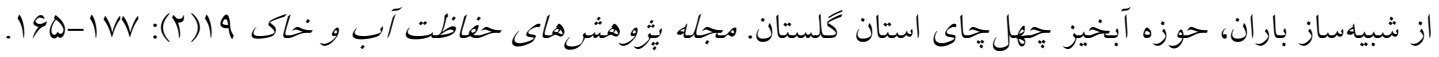

$$
\begin{aligned}
& \text { r. واعظى، ع. ر. و ح. قرهداغلى. rوجا. كمىسازى كسترش فرسايش شيارى در خاكهاى مارنى در حوزه آبخيز زنجانرود در شمال } \\
& \text { غرب زنجان، نشريه آب و خاك TV: }
\end{aligned}
$$

3. Abbasi, N., R. Bahramloo, M. Movahedan. 2015. Strategic planning for remediation and optimization of the magnitude of rill erosion in Belgium and northern France. Catena 114: 129-139.

4. Beyen, S. 2011. Toposequence in Gununo Area, Southern Ethiopia. Journal of Sciences and Development 1(1): 31-41.

5. Carter, M. R. and E. G. Gregorich. 2008. Soil Sampling and Methods of Analysis, Second Edition. Canadian Society of Soil Science Publisher. Canada.

6. Celso, A. G. 1997. Developing a sheet erosion equation for a semiarid region, human impact on erosion and sedimentation, In: Proceedings of the Rabat Symposium, Morocco, IAHS Publication. PP. 31-38.

7. Cerdà, A. 1997. The influence of aspect and vegetation on seasonal changes in erosion under rainfall simulation on a clay soil in Spain. Canadian Journal of Soil Science 78(2):321-330.

8. Chapman, H. D. and P. F. Pratt. 1978. Methods of Analysis for Soils, Plants and Waters. Division of Agricultural Sciences. University of California, USA.

9. Chen, L., Z. Huang, J. Gong, B. Fu and Y. Huang. 2007. The effect of land cover/vegetation on soil water dynamic in the hilly area of the loess plateau, China. Catena 70(2): 200-208.

10. Defersha, M., S. Quraishi and A. Melesse. 2011. The effect of slope steepness and antecedent moisture content on interrill erosion, runoff and sediment size distribution in the highlands of Ethiopia. Hydrology and Earth System Sciences 15(7): 2367-2375.

11. Descroix, L., D. González, J. Viramontes, E. Poulenard, M. Anaya and J. Estrada. 2008. Gully and sheet erosion on subtropical mountain slopes: Their respective roles and the scale effect. Catena 72: 325-339.

12. Dlamini, P., G. Orchard, S. Jewitt, P. Lorentz, L. Titshall and V. Chaplot. 2011. Controlling factors of sheet erosion under degraded grasslands in the sloping lands of KwaZulu-Natal, South Africa. Agricultural Water Management 98(11): 1711-1718.

13. Flanagan, D. 2002. Erosion Encyclopedia of Soil Science. Marcel Dekker, New York.

14. Geissen, V., R. Sanchez, C. Kampichler, R. Ramos, A. Sepulveda and S. Hernández. 2009. Effects of land-use change on some properties of tropical soils-An example from southeast Mexico. Geoderma 151: 87-97.

15. Gupta, S. K. and R. S. Chera. 1996. Soil characteristics as influenced by slope aspects in Middle Swiwaliks. Agropedology 6: 43-48.

16. Jacob, H. and T. Clarke. 2002. Methods of soil analysis. Soil Science Society of American Journal 4(1): 317-328.

17. Jordan, A. and L. Martinez-Zavala. 2008. Soil loss and runoff rates on unpaved forest roads in southern Spain after simulated rainfall. Forest Ecology and Management 255: 913-919.

18. Kateb, I., F. Zhang, C. Zhang and R. Mosandl. 2013. Soil erosion and surface runoff on different vegetation covers and slope gradients: a field experiment in Southern Shaanxi Province, China. Catena 105: 1-10.

19. Kimaro, D., J. Poesen, B. Msanya and J. Deckers. 2008. Magnitude of soil erosion on the northern slope of the Uluguru Mountains, Tanzania: Interrill and rill erosion. Catena 75(1): 38-44.

20. Klute, A. 1986. Methods of Soil Analysis. Part 1. Physical and Mineralogical Methods Medison Wisconsin, Unitate States of America.

21. Lenka, N. K., S. Sudhishri, A. Dass, P. R. Choudhury, S. Lenka and U. S. Patnaik. 2013. Soil carbon sequestration as affected by slope aspect under restoration treatments of a degraded alfisoil in the Indian sub-tropics. Geoderma 204: 102-110.

22. Maren, I. E., S. Karki, C. Prajapati, R. K. Yadav and B. B. Shrestha. 2015. Facing north or south: Does slope aspect impact forest stand characteristics and soil properties in a semiarid trans-Himalayan valley? Journal of Arid Environments 121: 112-123.

23. Nelson, D. W. and L. E. Sommer. 1982. Total carbon, organic carbon, and organic matter. In: A. L. Page (Ed.), 
Methods of Soil Analysis: Chemical and Microbiological Properties. American Society of Agronomy, Madison. PP. 539-579.

24. Pieri, L., M. Bittelli, M. Hanuskova, F. Ventura, A. Vicari and P. Rossi. 2009. Characteristics of eroded sediments from soil under wheat and maize in the North Italian Apennines. Geoderma 154: 20-29.

25. Qinjuan, M., C. Qiangguo and M. Wenjun. 2008. The relative importance of soil crust. Geo Journal 71: 117-125.

26. Rech, J. A., R. W. Reeces and D. M. Hendricks. 2001. The influence of slope aspect on soil weathering processes in the Springerville volcanic field, Arizona. Catena 43(1): 49-62.

27. Romero, C., L. Stroosnijder and G. A. Baigorria. 2007. Interrill and rill erodibility in the northern Andean Highlands. Catena 70(2): 105-113.

28. Shi, Z. H., N. F. Fang, F. Z. Wu, L. Wang, B. J. Yue and G. L. Wu. 2012. Soil erosion processes and sediment sorting associated with transport mechanisms on steep slopes. Journal of Hydrology 454: 123-130.

29. Sternberg, M. and M. Shoshany. 2001. Influence of slope aspect on Mediterranean woody formations: Comparison of a semiarid and an arid site in Israel. Ecology Research 16: 345-355.

30. Suhua, F., L. Baoyuan and L. Heping. 2011. The effect of slope on interrill erosion at short slopes, Catena 84(1): 29-34.

31. Tejada, M. J. and J. L. Gonzalez. 2007. Influence of organic amendments on soil structure and soil loss under simulated rain. Soil and Tillage Research 93(1): 197-205.

32. Vaezi, A. R., M. Abbasi, G. Bussi and S. Keesstra. 2016. Modeling sediment yield in semi-arid pasture micro-catchments, NW Iran. Land Deg Radation and Development 26: 186-199.

33. Wang, L. and M. Shao. 2008. Effects of tillage erosion on soil nutrients in loess sloping land of China. Transactions of the CSAE. Earth and Planetary Sciences 6: 63-67.

34. Wang, L., N. Dalabay, P. Lu and F. Wu. 2017. Effect of tillage practices and slope on runoff and erosion of soil from the loess Plateau, China, subjected to simulated rainfall. Soil and Tillage Research 166: 147-156.

35. Woo, M., G. Fang and D. Dicenzo. 1997. The role of vegetation in the retardation of rill erosion. Catena 29(2): 145-159.

36. Zhang, K., S. Li, W. Peng and B. Yu. 2004. Erodibility of agricultural soils and loess plateau of China. Soil and Tillage Research 76: 157-165.

37. Zingg, A. W. 2011. Degree and length of land slope as it affects soil loss in run-off. Agricultural Engineering 21: 59-64. 


\title{
Variability of Surface Erosion and Particle Size Distribution in Relation to Slope Aspect and Gradient in a Semi-Arid Region in West of Zanjan
}

\author{
A. R. Vaezi* ${ }^{*}$ Z. Bayat and M. Foroumadi ${ }^{1}$
}

(Received: February 18-2017; Accepted: April 18-2017)

\begin{abstract}
Soil erosion by surface runoff introduced as surface erosion is one of the main mechanisms of land degradation in the hill slopes. Slope characteristics including aspect and gradient can control the differences of soil properties along the hillslope. This study was conducted to investigate the effect of slope aspect and gradient on variations of some soil properties in the short slopes. Five hills including both north and south aspects with different gradients (9-10\%, $13-16 \%, 17-22 \%, 29-31 \%$ and $33-37 \%$ ) were considered in a semi-arid region with 30 ha in area, in the west of Zanjan, northwest of Iran. The hills were weakly covered with pasture vegetation covers. Soil samples were collected along the slopes from two depths $(0-5 \mathrm{~cm}$ and $5-15 \mathrm{~cm})$ in four positions with $2 \mathrm{~m}$ distance along each slope with two replications. A total of 160 soil samples were analyzed for particle size distribution (sand, silt and clay), gravel and bulk density. Surface erosion was determined based on the variation of grain size distribution and bulk density. Differences of the grain size distribution and surface erosion between the two slope aspects and among the slope gradients were analyzed using the Tukey test. No significant difference was found between slope aspects in surface soil erosion. Nevertheless, surface soil erosion was affected by slope gradient in each slope aspect $\left(\mathrm{R}^{2}=0.78, \mathrm{p}<0.05\right)$. Surface erosion in the north slopes was more dependent on the slope gradient, as compared to the corresponding south slopes. In the south slopes, surface erosion was affected by the movement of silt particles from soil surface, while in the north slopes, it was significantly affected by the loss of clay particles.
\end{abstract}

Keywords: Particle size distribution, Soil properties, South slope, North slope, Surface erosion

1. Department of Soil Science, Faculty of Agriculture, University of Zanjan, Zanjan, Iran.

*: Corresponding Author, Email: vaezi.alireza@gmail.com 